\title{
Physicochemical evaluation of bore-hole water from selected fish farms in Edo State, Nigeria
}

\author{
E. E. OBASOHAN \\ Department of Animal Science, Faculty of Agriculture, Ambrose-Alli University, Ekpoma, Edo State, Nigeria. \\ E-mail: ewaensohan@yahoo.com
}

\begin{abstract}
This study investigated the physical and chemical properties of water from bore-holes in selected fish farms in the three districts of Edo State, Nigeria. Sample collection, treatment and determination of physical and chemical properties were according to approved standards. The results showed that all the parameters analyzed were within the required standards for aquaculture and drinking purposes, except $\mathrm{pH}$ which was slightly acidic, alkalinity in Edo South which was very low, and the metals $\mathrm{Mn}$ and $\mathrm{Pb}$ whose concentrations exceeded the standard limits for drinking water. Based on the acceptable levels of most of the parameters, it was concluded that the water of the study area was suitable for aquaculture, drinking and other domestic purposes. However, because of the $\mathrm{pH}$ and the heavy metals $\mathrm{Mn}$ and $\mathrm{Pb}$, it was recommended that the water be treated with lime before use especially in aquaculture facilities, in order to increase $\mathrm{pH}$ and possibly reduce metal concentrations to tolerable limits through precipitation and or adsorption, to sediment particles and thus lead to production of suitable fish for consumers.

(c) 2009 International Formulae Group. All rights reserved.
\end{abstract}

Keywords: Physicochemical properties, Bore-hole, Water, Aquaculture, Edo State.

\section{INTRODUCTION}

The desirability of good water for maximum fish production is acknowledged (CIFA, 1994; Ogbeibu and Ezeunara, 2002; Akolisa and Okonji, 2005; Asonye et al., 2007). According to the European Inland Fisheries Advisory Commission (EIFAC) of the Food and Agriculture Organization (FAO, 1992), water quality criteria for freshwater fish should permit all stages in the life cycle to be successfully completed and should not produce conditions which would either taint the flesh of the fish or cause them to avoid a stretch of the water body, where they would otherwise be present, or give rise to accumulation of deleterious substances in fish to such a degree that they are potentially harmful when consumed (CIFA, 1994). Unfortunately, water supplies have become contaminated from both natural and anthropogenic sources, which have impacted on the health and economic status of populations (FAO, 1992; Asonye et al., 2007). Pollution of surface waters has had severe impacts on natural fisheries production whose resources have continued to diminish with increasing human population (Olowosegun et al., 2005).

It is therefore no surprise that emphasis in fish production has shifted towards aquaculture, which is currently one of the fastest food production systems in the world, with an annual growth rate of $11.2 \%$ per year (Williams, 1996; Delgado et al., 2003; Akolisa and Okonji, 2005).

In Nigeria, aquaculture production increased from 20,475 metric tons in 1983 to 30,000 metric tons in 2005 (Olaniyi, 2005). Delgado et al. (2003) stated that on global basis, aquaculture production has been the 
only engine of growth in food fish production and hopes have risen that aquaculture may ease pressure on threatened wild fish stocks.

However, interactions between aquaculture and changes in the environment induced by human activities are becoming increasingly important. Pollution from urbanization, industrialization, intensification of agriculture and oil exploitation, and conveyance may kill fish directly in aquaculture facilities or affect the quality and consumer acceptance of the product (Akolisa and Okonji, 2005).

Underground (bore-hole) water to which many Aqua-culturists have turned to as source of water may also be affected for both present and future uses. According to Parker (1986), pollution irrespective of the origin will cause stress to fish leading to production of catecholamine or corticosteroids. Normal gill functions will eventually be disrupted resulting in protein catabolism, accompanied by weight loss and reduced growth, disease and mortality (Parker, 1986; Akolisa and Okonji, 2005).

In Edo State, Nigeria (Figure 1), there is an increasing use of bore-hole (underground) water in aquaculture, especially in Edo South District where the water table (aquifer) is high and easily accessed without much sophisticated technology. Besides, this source of water is sufficient in volume to meet the requirements for both aquaculture and drinking/domestic uses (Essiensberg Consultants Limited, 1994). However, current information on the quality of the underground water, especially for aquaculture purposes is lacking.

It is against this general background that this study, which determined the physicochemical parameters of bore-hole water from selected fish farms in Edo State was embarked upon. The main objective is to examine the quality of bore-hole water to aquaculture, with a view to improving both the productivity and the quality of products from aquaculture facilities in the State. Other objectives are to evaluate bore-hole water supply for drinking and other domestic purposes. Earlier reports and investigations by Esssiensberg Consultants (1994), Ademoroti (1996), Ihuahi and Omojowo (2005), and Asonye et al. (2007) on water quality parameters, which included levels of some dissolved ions $\left(\mathrm{Ca}^{++}, \mathrm{Mg}^{++}, \mathrm{Fe}^{++}, \mathrm{Na}^{++}\right.$etc) and other microbiological studies indicated that underground water of the area is suitable for drinking/domestic purposes, but these studies were not exhaustive. The present study aims at complimenting these efforts. Another justification for this study is that Aquaculturists depend on this source of water for their drinking and other domestic uses.

\section{MATERIALS AND METHODS}

Bore-holes from selected aquaculture facilities (fish farms and homestead concrete tanks) from the three Districts (Edo South, Edo Central and Edo North) of Edo State were sampled in this study. 25 bore-holes were from Benin City in Oredo, Uhunmwode and Ovia communities in Edo South, while 12 were from Ekpoma, Uromi and Ubiaja communities in Edo Central and Sabongidda, Oke, Afuze/Egeuno, Fugar and Agenebode in Owan/Etsako communities in Edo North District (Figure 1).

Water samples were collected into plastic bottles, which had been previously washed and stored overnight in aqua regia. Samples for heavy metal analysis were acidified with $\mathrm{HNO}_{3}$, while the ones for other parameters except those determined at site, were stored in an ice box from the sampling site to the laboratory.

Water samples were analyzed for Temperature, pH, Dissolved Oxygen (DO), Conductivity, Biological Oxygen Demand (BOD), Total Dissolved Solids (TDS), Alkalinity, Chloride $\left(\mathrm{Cl}^{-}\right)$, Sulphates $\left(\mathrm{SO}_{4}{ }^{2-}\right)$, Phosphates $\left(\mathrm{PO}_{4}{ }^{3-}\right)$, Nitrates $\left(\mathrm{NO}_{3}{ }^{-}\right)$, Nitrites $\left(\mathrm{NO}_{2}{ }^{-}\right)$, and Ammonium-nitrogen $\left(\mathrm{NH}_{4}-\mathrm{N}\right)$ and some selected heavy metals $(\mathrm{Cu}, \mathrm{Cd}, \mathrm{Mn}$, $\mathrm{Zn}$ and $\mathrm{Pb}$ ).

Parameters such as Temperature, $\mathrm{pH}$, TDS, DO, and Conductivity were determined at site. Titrimetry was used to determine Alkalinity and Chloride content. Atomic Absorption Spectrophotometer (Solar 960 Unicam Series) was used to determine the concentrations of the heavy metals, while the Cecil 8000 UV-Visible Spectrophotometer was used to determine $\mathrm{SO}_{4}{ }^{2-}, \mathrm{PO}_{4}{ }^{3-}, \mathrm{NO}_{3}{ }^{-}$, $\mathrm{NO}_{2}{ }^{-}$and $\mathrm{NH}_{4}-\mathrm{N}$.

Statistical analysis was carried out using the Analysis of Variance (ANOVA) of the Completely Randomized Design (CRD). Level of significance used was $\mathrm{P}>0.05$. 


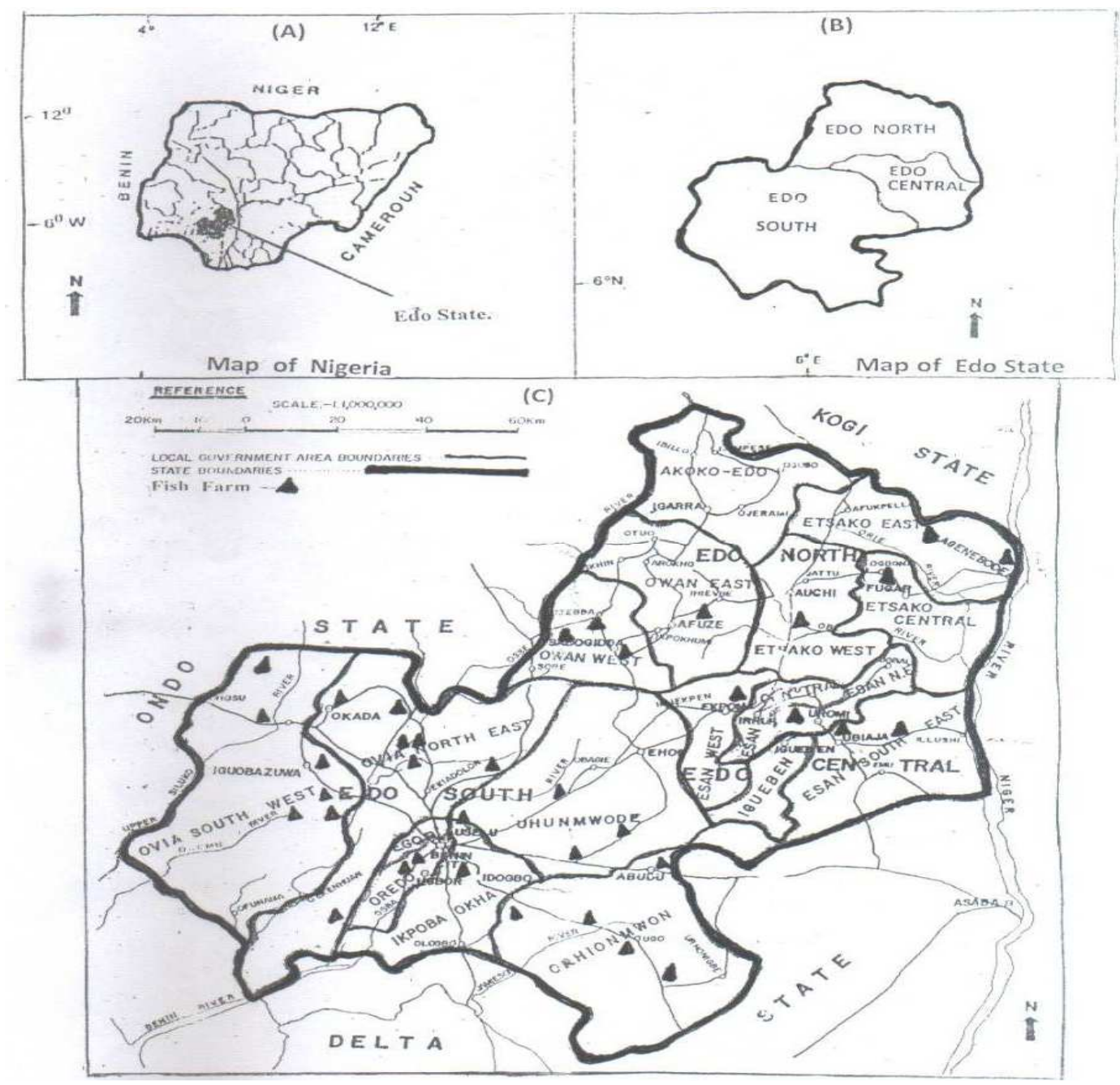

Figure 1: (A) Map of Nigeria showing location of Edo State. (B) Map of Nigeria showing the Senatorial Districts. (C) Map of Nigeria showing location of sampled fish farms.

\section{RESULTS}

The results of the analysis of the physicochemical parameters are presented in table 1 .

\section{Water temperature}

Water temperature values in the samples from the three Districts ranged between 26.85 and $28.4^{\circ} \mathrm{C}$. In Edo South, the range of values was $27.0-28.4{ }^{\circ} \mathrm{C}$, while the range of values for Edo Central and Edo North were 26.9-27.0 ${ }^{\circ} \mathrm{C}$ and $26.9-27.1{ }^{\circ} \mathrm{C}$ (Table 1). The respective mean values of the Districts were 27.35 \pm 0.35 (Edo South), $26.85 \pm 0.05$ (Edo Central) and 27.03 \pm 0.10 (Edo North). There were no significant differences $(\mathrm{P}>0.05)$ in water temperature across the three districts.

pH

The variations in $\mathrm{pH}$ levels of water samples of the three districts are as presented in Table 1. The values were 5.8-6.4 (Edo South), 6.5-6.8 (Edo Central) and 6.0-6.4 (Edo North). Water $\mathrm{pH}$ mean values were 6.28 $\pm 0.14 \quad$ (Edo South), 6.63 \pm 0.13 (Edo Central) and 6.23 \pm 0.17 (Edo North). pH mean values in Edo Central was higher than those of Edo South and Edo North, but the differences across the districts were not significant $(\mathrm{P}>0.05)$. 
Table 1: Summary of physicochemical parameters of bore-hole water of the study area.

\begin{tabular}{|c|c|c|c|c|c|c|c|c|c|c|}
\hline \multirow[b]{2}{*}{ No. } & \multirow[b]{2}{*}{ Parameter } & \multicolumn{9}{|c|}{ EDO SOUTH } \\
\hline & & Min & $\operatorname{Max}$ & Mean & Min & $\operatorname{Max}$ & Mean & Min & $\operatorname{Max}$ & Mean \\
\hline 1 & Temp. $\left({ }^{\circ} \mathrm{C}\right)$ & 27.0 & 28.4 & $27.35 \pm 0.35$ & 26.9 & 27.0 & $26.85 \pm 0.05$ & 26.9 & 27.1 & $27.03 \pm 0.10$ \\
\hline 2 & Conductivity & 26.8 & 131.50 & $57.19 \pm 24.95$ & 23.2 & 69.0 & $46.78 \pm 25.02$ & 36.2 & 37.5 & $36.7 \pm 0.59$ \\
\hline 3 & $\mathrm{pH}$ & 5.8 & 6.4 & $6.28 \pm 0.14$ & 6.5 & 6.8 & $6.63 \pm 0.13$ & 6.0 & 6.4 & $6.23 \pm 0.17$ \\
\hline 4 & TDS.(mg/l) & 16.09 & 78.80 & $34.24 \pm 14.94$ & 13.81 & 41.4 & $27.90 \pm 0.32$ & 21.6 & 22.4 & $21.93 \pm 0.39$ \\
\hline 5 & Alkalinity ,, & 12.20 & 15.25 & $13.04 \pm 0.74$ & 24.40 & 48.80 & $33.44 \pm 10.69$ & 27.5 & 140.30 & $70.73 \pm 25.92$ \\
\hline 6 & DO (mg/l) & 12.63 & 15.00 & $13.94 \pm 0.59$ & 12.00 & 18.50 & $15.97 \pm 3.15$ & 9.50 & 17.75 & $14.69 \pm 3.86$ \\
\hline 7 & BOD (mg/l) & 3.38 & 9.75 & $7.25 \pm 1.44$ & 3.75 & 11.37 & $7.34 \pm 4.16$ & 2.37 & 10.25 & $6.25 \pm 3.84$ \\
\hline 8 & Chloride , & 35.50 & 85.20 & $57.10 \pm 22.04$ & 35.50 & 58.60 & $44.83 \pm 15.32$ & 35.50 & 71.00 & $50.15 \pm 20.50$ \\
\hline 9 & Sulphate , & 0.08 & 0.97 & $0.87 \pm 0.05$ & 0.73 & 0.75 & $0.74 \pm 0.002$ & 0.73 & 0.80 & $0.76 \pm 0.002$ \\
\hline 10 & Phosphate , & 0.02 & 0.55 & $0.21 \pm 0.04$ & 0.01 & 0.06 & $0.03 \pm 0.02$ & 0.05 & 0.41 & $0.18 \pm 0.06$ \\
\hline 11 & Nitrate & 0.00 & 0.10 & $0.04 \pm 0.002$ & ND & ND & - & ND & ND & - \\
\hline 12 & $\mathrm{NH}_{4}-\mathrm{N} \quad$, & 0.00 & 1.74 & $0.69 \pm 0.005$ & ND & ND & - & ND & ND & - \\
\hline 13 & $\mathrm{Cu}(\mathrm{mg} / \mathrm{l})$ & 0.034 & 0.06 & $0.05 \pm 0.004$ & 0.13 & 0.44 & $0.24 \pm 0.13$ & 0.16 & 0.32 & $0.23 \pm 0.07$ \\
\hline 14 & $\mathrm{Mn}(\mathrm{mg} / \mathrm{l})$ & 3.95 & 6.82 & $4.94 \pm 0.39$ & 5.18 & 7.49 & $6.46 \pm 1.38$ & 6.40 & 6.86 & $6.53 \pm 0.22$ \\
\hline 15 & $\mathrm{Zn}(\mathrm{mg} / \mathrm{l})$ & 0.81 & 1.78 & $1.09 \pm 0.17$ & 0.96 & 1.05 & $1.02 \pm 0.003$ & 0.90 & 1.09 & $0.97 \pm 0.02$ \\
\hline 16 & $\mathrm{Cd}(\mathrm{mg} / \mathrm{l})$ & ND & ND & - & ND & ND & - & ND & ND & - \\
\hline 17 & $\mathrm{~Pb}(\mathrm{mg} / \mathrm{l})$ & 0.35 & 0.87 & $0.54 \pm 0.24$ & 0.34 & 0.92 & $0.50 \pm 0.08$ & 0.39 & 0.82 & $0.61 \pm 0.22$ \\
\hline 18 & $\mathrm{Ni}(\mathrm{mg} / \mathrm{l})$ & ND & ND & - & ND & ND & - & ND & ND & - \\
\hline
\end{tabular}

\section{Conductivity}

Conductivity values ranges were 26.8$131.50 \mu \mathrm{s} / \mathrm{cm}$ (Edo South), 23.2-69.0 $\mu \mathrm{s} / \mathrm{cm}$ (Edo Central) and 36.2-37.5 $\mu \mathrm{s} / \mathrm{cm}$ (Edo North) (Table 1). Mean conductivity levels were a maximum of $57.10 \pm 24.95$ (Edo South), $46.78 \pm 25.02$ (Edo Central) and a minimum of 36.70 \pm 0.59 (Edo North) (Table 1). Conductivity mean values were different $(\mathrm{P}<0.05)$ among the three districts.

\section{Total dissolved solids (TDS)}

TDS in samples from Edo South were a range 16.09-78.80 $\mathrm{mg} / \mathrm{l}$ with a mean of $34.24 \pm 14.94$ (Table 1). Samples from Edo Central had TDS range of 13.81-41.4 mg/l with a mean of $27.90 \pm 0.32$, while those from Edo North had a TDS range of 21.6-22.4 mg/l and a mean of $21.93 \pm 0.39$ (Table 1). TDS variations among the districts were not significantly different $(\mathrm{P}>0.05)$.

\section{Alkalinity}

Analysis of water samples for alkalinity recorded values in the range 12.20-15.25 mg/l for Edo South, while those from Edo Central and Edo North recorded ranges of 24.40-48.80 $\mathrm{mg} / \mathrm{l}$ and 27.45-140.30 mg/l (Table 1). The mean values for the different districts were
13.04 \pm 0.74 (Edo South), 33.44 \pm 10.69 (Edo Central) and 70.73 \pm 25.92 (Edo North) (Table 1). Alkalinity mean values were different $(\mathrm{P}<0.05)$ among the districts.

\section{Dissolved oxygen (DO)}

DO values were in the range 12.63$15.00 \mathrm{mg} / \mathrm{l}$ with a mean of $13.94 \pm 0.59$ for Edo South and $12.00-18.50 \mathrm{mg} / \mathrm{l}$ with a mean of 15.97 \pm 3.15 for Edo Central (Table 1). Edo North had values in the range 9.50-17.75 mg/l with a mean of $14.69 \pm 3.86$. The variations of DO in the districts were not significantly different $(\mathrm{P}>0.05)$.

\section{Biological dissolved oxygen (BOD)}

BOD levels were in the range 3.38-9.75 $\mathrm{mg} / \mathrm{l}$ (Edo South), 3.75-11.37 mg/l (Edo Central) and 2.37-10.25 mg/l (Edo North) (Table 1). BOD mean values for Edo South, Edo Central and Edo North were 7.25 \pm 1.44 , $7.34 \pm 4.16$ and $6.25 \pm 3.84 \mathrm{mg} / \mathrm{l}$ respectively (Table 1). BOD mean values of the water samples of the districts were not significantly different $(\mathrm{P}>0.05)$.

\section{Chloride $\left(\mathrm{Cl}^{-}\right)$}

Chloride values recorded were in the range 35.50-85.20 mg/l (Edo South), 35.50- 
$58.60 \mathrm{mg} / \mathrm{l}$ (Edo Central) and 35.50-71.00 $\mathrm{mg} / \mathrm{l}$ (Edo North) (Table 1). The mean values at the different districts were $57.10 \pm 22.04$ (Edo South), 44.83 \pm 15.32 (Edo Central) and $50.15 \pm 20.50$ (Edo North) (Table 1).The variations across the three districts were not significantly different $(\mathrm{P}>0.05)$ at $5 \%$ confidence level (Table 1).

\section{Sulphate $\left(\mathrm{SO}_{4}{ }^{2-}\right)$}

Sulphate values ranged between a minimum of $0.73-0.75 \mathrm{mg} / \mathrm{l}$ (Edo Central) and a maximum of $0.80-0.97 \mathrm{mg} / \mathrm{l}$ (Edo South) (Table 1). The values recorded in Edo North were in the range $0.73-0.80 \mathrm{mg} / \mathrm{l}$. Mean values recorded at the three districts were $0.87 \pm 0.05$ $\mathrm{mg} / \mathrm{l}$ (Edo South), 0.74 $\pm 0.002 \mathrm{mg} / \mathrm{l}$ (Edo Central) and $0.76 \pm 0.002 \mathrm{mg} / \mathrm{l}$ (Edo North) (Table 1). Mean values among the three districts were not statistically different $(\mathrm{P}>0.05)$.

\section{Phosphate $\left(\mathrm{PO}_{4}{ }^{3-}\right)$}

$\mathrm{PO}_{4}{ }^{3-}$ values obtained in this study ranged from $0.02-0.55 \mathrm{mg} / \mathrm{l}$ (Edo South), 0.01-0.06 mg/l (Edo Central) to 0.05-0.41 $\mathrm{mg} / \mathrm{l}$ (Edo North) (Table 1). The minimum mean value $(0.03 \pm 0.02 \mathrm{mg} / \mathrm{l})$ was recorded in Edo Central, while the maximum mean value of $0.18 \pm 0.06 \mathrm{mg} / \mathrm{l}$ was recorded in Edo North. The mean value in Edo South was $0.21 \pm 0.04$ $\mathrm{mg} / \mathrm{l}$ (Table 1). Phosphate mean values were different $(\mathrm{P}<0.05)$ among the districts

\section{Nitrate $\left(\mathrm{NO}_{3}{ }^{-}\right)$and ammonium-nitrogen $\left(\mathrm{NH}_{4}-\mathrm{N}\right)$}

Nitrate and ammonium-nitrogen were detected only in the water of Edo South with low values of the range $0.00-0.01 \mathrm{mg} / \mathrm{l}$ for nitrate and $0.0-1.74 \mathrm{mg} / \mathrm{l}$ for ammoniumnitrogen $\left(\mathrm{NH}_{4}-\mathrm{N}\right)$ (Table 1$)$.

\section{Heavy metals}

The heavy metals analyzed in this study were $\mathrm{Cu}, \mathrm{Cd}, \mathrm{Mn}, \mathrm{Ni}, \mathrm{Zn}$ and $\mathrm{Pb} . \mathrm{Cd}$ and $\mathrm{Ni}$ were not detected in the water samples (Table $1)$. For $\mathrm{Cu}$, the values were in the range 0.034$0.06 \mathrm{mg} / \mathrm{l}$ (Edo South), 0.13-0.44 mg/l (Edo Central) and 0.16-0.32 mg/l (Edo North). Mn values were 3.95-6.82 mg/l (Edo South), 5.18$7.49 \mathrm{mg} / \mathrm{l}$ (Edo Central) and 6.40-6.86 mg/l (Edo North). Zn values were 0.81-1.78 mg/l (Edo South), 0.96-1.05 mg/l (Edo Central) and 0.90-1.09 mg/l (Edo North). The values for $\mathrm{Pb}$ were $0.35-0.87 \mathrm{mg} / \mathrm{l}, 0.34-0.92 \mathrm{mg} / \mathrm{l}$ and 0.39 $0.82 \mathrm{mg} / \mathrm{l}$ respectively for Edo South, Edo Central and Edo North. The mean values for the various metals are shown in Table 1.

\section{DISCUSSION \\ Water temperature}

Water temperature expressed in degrees Celsius $\left({ }^{\circ} \mathrm{C}\right)$ is an important parameter regarding its effects on the solubility of oxygen in water, the rate of photosynthesis by algae and higher plants, the metabolic rates of aquatic organisms and the sensitivity of organisms to toxic wastes, parasites and diseases. The water temperatures recorded in the three districts in this study were within the range $25-32{ }^{\circ} \mathrm{C}$ for tropical waters. Fishes are poikilothermic animals and their metabolic rate is regulated by the temperature of the surrounding water. Temperature has a pronounced effect on chemical and biological processes. According to Carvalho et al. (2004), all life processes of living organisms are physicochemical in nature and are therefore affected by temperature. In general, the rate of chemical and biological reactions doubles for $10{ }^{\circ} \mathrm{C}$ increase in temperature and as the temperature changes, the rate of various processes must be balanced and coordinated and the organism must compensate or minimize the changes in its body (Tait, 1968; Carvalho et al., 2004). The oxygen requirement of fish is more critical in warm water than in cooler water. Toxicity of heavy metals increases with higher water temperatures (Nussey et al., 2006). The Rainbow trout in zinc sulphate solution survived 2.35 times longer when the temperature was lowered from $22{ }^{\circ} \mathrm{C}$ to $12{ }^{\circ} \mathrm{C}$ (Forstner and Wittman, 1981). Temperature values recorded in this study were all within the acceptable range of $20-30{ }^{\circ} \mathrm{C}$ required for optimum fish yield in warm water aquaculture (Boyd, 1979; Izevbigie, 2005).

\section{pH}

$\mathrm{pH}$ is a general measure of the acidity or alkalinity of a water sample and is indicated on a scale of $0-14$. The $\mathrm{pH}$ of natural waters is determined largely by geological and atmospheric influences (DWAF, 1993). The mean values recorded in Edo South $(6.28 \pm 0.14)$ and Edo North $(6.23 \pm 0.17)$ were slightly lower than the WHO (2004) 
recommended values (6.5-8.5) for drinking water. Low $\mathrm{pH}$ has been reported to lead to the mobilization of elements such as iron, aluminium, cadmium, copper, lead etc (DEAT, 1999). However the treatment of water with alum (sulphates of aluminium and potassium) to boost the $\mathrm{pH}$ of water used for drinking and other domestic purposes is common in the area and could minimize any excessive metal mobilization. $\mathrm{pH}$ mean values across the three districts however fall within the acceptable range for aquaculture. Fish grows better at a $\mathrm{pH}$ range of 6-9 (Boyd, 1979) and Tilapia has been reported to either die or stop reproduction at a $\mathrm{pH}$ of 3.5 or basic pH above 9 (Kutty, 1987).

\section{Conductivity}

Conductivity is a numerical expression of the ability of water to conduct an electrical current, resulting from the presence of charged species in solution (DWAF, 1993). Conductivity is influenced by an array of factors, for example the concentration and nature of the solutes, their degree of dissociation into ions, their electrical charges, the mobility of the ions and the temperature of the solution. Mean conductivity levels recorded in this study were progressively lower from Edo South (57.10 \pm 24.95$)$ through Edo Central $(46.78 \pm 25.02)$ to Edo North $(36.70 \pm 0.59)$ and may not be unconnected with the progressive increase in depth of underground water (aquifer) and differences in levels of total dissolved ions across the three districts from Edo South to Edo North. Conductivity values in the districts were low in comparison to the 200-600 $\mu \mathrm{s} / \mathrm{cm}$ maximum acceptable limits in drinking water (WHO, 2004). Similarly low conductivity values have been reported for many surface waters in the area (Ogbeibu and Victor, 1995; Edokpayi and Osime, 2001; Oguzie, 2003). Water with low conductivities has been reported suitable for aquaculture (Gietema, 1992; Izevbigie, 2005). It is conceivable therefore that the water of the study area as far as conductivity is concerned, is suitable for aquaculture, drinking and other domestic uses.

\section{Total dissolved solids (TDS)}

TDS values as recorded in this study were relatively higher $(34.24 \pm 14.94 \mathrm{mg} / \mathrm{l})$ in Edo South water samples than those of samples from Edo Central $(27.90 \pm 0.32 \mathrm{mg} / \mathrm{l})$ and Edo North $(21.93 \pm 0.39 \mathrm{mg} / \mathrm{l})$. This could be linked to higher volume of rainfall and associated runoffs loaded with debris and mineral salts in Edo South. Geographically, Edo South is located in the Rain Forest zone and experiences heavier rainfall than Edo Central and Edo North located in the semi derived savannah with less rainfall. TDS values recorded in this study were low in comparison to the maximum acceptable limit of $500 \mathrm{mg} / \mathrm{l}$ required for aquaculture (WHO, 2003) as well as for drinking and other domestic purposes (Ademoroti, 1996) and indicated that bore-hole water of the study area is suitable for aquaculture, drinking and domestic purposes.

\begin{abstract}
Alkalinity
Alkalinity values recorded in this study showed that alkalinity levels in Edo South were comparatively lower $(\mathrm{P}<0.05)$ than those from Edo Central and Edo North (Table 1). This is in tandem with the report by Sutcliffe et al. (1998), that low concentrations are usually associated with heavy rainfall due to influx of organic matter and salts by rain water runoffs. Alkalinity values which ranged from $12.20-140.0 \mathrm{mg} / \mathrm{l}$ in the study area were considered suitable for aquaculture in view of the fact that FEPA (2003) and DPR (1991) recommended a range of $30-150 \mathrm{mg} / \mathrm{l}$ for optimum fish productivity in aquaculture. The Committee on Water Quality Criteria of the US Department of Interior (1968) and FEPA (2003) also recommended the same range (30$150 \mathrm{mg} / \mathrm{l})$ of alkalinity for domestic water use. Based on the above, alkalinity levels of the water of the study areas recorded in this study were also considered suitable for drinking and other domestic uses, except in Edo South, where lower value $(13.04 \pm 0.74)$ was recorded. However, earlier reports and investigations by Essiensberg Consultants Limited (1994) and Adomoroti (1996) have recorded higher alkalinity and low water hardness levels in Edo South and concluded that underground water of the study area was suitable for drinking and other domestic purposes. Further investigation in this area is advocated in Edo South, in view of the very low alkalinity recorded in this study, which contrasted with these earlier reports.
\end{abstract}




\section{Dissolved oxygen (DO)}

An analysis of dissolved oxygen measures the amount of gaseous oxygen dissolved in an aqueous solution. The maintenance of adequate dissolved oxygen concentrations is critical for the survival of aquatic biota. DO mean values which were recorded in this investigation were high in comparison with WHO (2003) and FEPA (2003) recommendations of $6.29 \mathrm{mg} / \mathrm{l}$ and 5 $\mathrm{mg} / \mathrm{l}$ for drinking water. In fish, Gietema (1992) reported that DO above $4.5 \mathrm{mg} / \mathrm{l}$ induce good growth rate and favourable food conversion, while levels of $2-4.5 \mathrm{mg} / \mathrm{l}$ induce loss of appetite and unfavourable food conversion. Gietema, 1992 also reported that levels less than $2.0 \mathrm{mg} / \mathrm{l}$ were reported harmful leading to gasping, sub-lethal and lethal effects. High DO levels in aquaculture facilities means sufficient oxygen for fish and aquatic organisms in the medium and by implication high fish productivity (Boyd, 1979).

\section{Biological dissolved oxygen (BOD)}

BOD is a measure of oxygen consumed in any body of water in $\mathrm{mg} / \mathrm{l}$ under laboratory conditions during the biological processes that breakdown organic matter into simple substances over a period of 5 days by microbes usually bacteria (Ademoroti, 1996). High BOD is a sign of organic pollution (Egborge, 1994). If the BOD is too high, it will cause asphyxiation of fish and other organisms due to high consumption of oxygen by microbes (Idodo-Umeh, 2002). The highest mean level recorded in this study was $7.34 \pm 4.16 \mathrm{mg} / \mathrm{l}$ (Edo Central), which is lower than the $10 \mathrm{mg} / \mathrm{l}$ recommendation of FEPA (2003). The above indicated that the organic pollution level in the study area was acceptable and the water suitable for aquaculture, drinking and for other domestic uses. This was expected in view of the high DO levels recorded in the water samples of the area.

\section{Chloride $\left(\mathrm{Cl}^{-}\right)$}

Chloride in surface and groundwater come from both natural and anthropogenic sources such as sedimentary rocks, runoffs containing de-icing salts, the use of inorganic fertilizers, landfill leachates and septic tanks (Bond et al., 1973; Wetzel, 1975). Chloride in water is mostly in the form of sodium chloride, potassium chloride and calcium chloride. Chloride concentration in excess of $100 \mathrm{mg} / \mathrm{l}$ impacts a salty taste (Bond et al., 1973) although consumers can become accustomed to levels in excess of $250 \mathrm{mg} / \mathrm{l}$. Although WHO (2004) proposed no healthbased guideline for chloride in drinking water, Bond et al. (1973) reported that chloride concentration in excess of $100 \mathrm{mg} / \mathrm{l}$ could cause physiological damage. The concentrations of chloride recorded in this study, fall below this value and the maximum limit of $200 \mathrm{mg} / \mathrm{l}$ set by WHO, 2003 and FEPA, 2003. Based on the above, the water of the study area, as far as chloride is concerned is considered suitable for aquaculture as well as for drinking and other domestic purposes.

\section{Sulphate $\left(\mathrm{SO}_{4}{ }^{2-}\right)$}

Sulphate values recorded in the three study districts, which range was 0.73-0.97 $\mathrm{mg} / \mathrm{l}$ in comparison to the recommended maximum permissible concentrations of 200 , $<250$ and $200 \mathrm{mg} / \mathrm{l}$ respectively of WHO (2003), Canada Drinking Water Standards and Objectives (1968) and FEPA (2003) were low. They were also low in comparison to the mean value of $13.50 \mathrm{mg} / \mathrm{l}$ reported for African rivers (Beauchamp, 1953) and the 7-10 mg/l in Burkina-Faso reservoirs (Etienne et al., 1997). The low sulphate values of this study could be due to underlying sedimentary rocks low in sulphate. Beauchamp (1953) attributed low sulphate values in African waters to their underlying sedimentary rocks which are low in sulphate. Sulphate concentrations above $750 \mathrm{mg} / \mathrm{l}$ have been reported to have laxative effects (Bond et al., 1973). The low sulphate values of the water of the studied districts indicated that the water of the area is good for drinking and other domestic uses as well as for aquaculture.

\section{Phosphate $\left(\mathrm{PO}_{4}{ }^{3-}\right)$}

Phosphate mean values of the water of the study areas compare with the $0.26 \mathrm{mg} / \mathrm{l}$ (WHO, 2003) and the $0.20 \mathrm{mg} / \mathrm{l}$ (Canada Drinking Water Standards and Objectives, 1968) limits, but low in comparison to FEPA, 2003 maximum acceptable limit of $5 \mathrm{mg} / \mathrm{l}$. These values indicated that phosphate is not a limiting factor in the water of the area even though biological productivity is mostly 
limited by the amount of phosphorus in freshwater and soil (Kutty, 1987; Abohweyere, 1990). Consequently, the water of the study area, as far as phosphate is concerned, could be said to be suitable for aquaculture, for drinking and other domestic uses.

\section{Nitrate $\left(\mathrm{NO}_{3}{ }^{-}\right)$}

The results of nitrate analysis (Table 1) showed that nitrate was very low in the water of the area, as it was detected only in Edo South. The range of nitrate values $(0.00-0.01$ $\mathrm{mg} / \mathrm{l})$ recorded were lower than the maximum acceptable levels of 20,45 and $<50 \mathrm{mg} / \mathrm{l}$ of FEPA (2003), WHO (2003) and Canadian Drinking Water Standards and Objectives (1968). Similarly low nitrate values were recorded in Ikpoba River in the area by Ogbeibu and Ezeunara (2002). Nitrate is the major form of nitrogen used by phytoplankton (Kutty, 1987), and its level in water increases with the increase in microbial activities (bacteria and fungi). Bond et al. (1973) reported that excess nitrates in water impacts bitter taste and water from shallow wells containing more than $45 \mathrm{mg} / \mathrm{l}$ could cause methemoglobinemia (blue-baby) in infants. The low nitrate levels recorded in the water samples are expected, taking into account the fact that underground water is usually low in nitrates due to reduced microbial activities. It can thus be inferred that as far as nitrate is concerned, the water of the study area is suitable for aquaculture, drinking and other domestic purposes.

\section{Ammonium-nitrogen $\left(\mathrm{NH}_{4}-\mathrm{N}\right)$}

Ammonium-nitrogen levels (0.00-1.74 $\mathrm{mg} / \mathrm{l})$ recorded only in Edo South in this study, were below the recommended limits of $0.5 \mathrm{mg} / \mathrm{l}$ and $0.2 \mathrm{mg} / \mathrm{l}$ in drinking water set by WHO, 2003 and FEPA, 2003. These very low levels may be due to low level microbial activities at the depth from which the underground water was obtained. High ammonium ions in water indicate high rate of organic pollution due to denitrification of organic matter by bacteria (Etienne et al., 1997). Gietema (1992) reported that under high temperature and $\mathrm{pH}$, ammonium ions will volatilize to ammonia and water. Ammonia in solution is very toxic to man and especially to fish. The low levels of ammonium-nitrogen recorded in this study, indicated that the water of the study area is suitable for the envisaged uses (aquaculture, drinking and other domestic uses).

\section{Heavy metals}

Except for $\mathrm{Cu}$, which the mean value was significantly lower in Edo South, all the other metals recorded non significantly different $(\mathrm{P}>0.05)$ mean values across the districts. Of the metals detected, $\mathrm{Cu}$ and $\mathrm{Zn}$ levels were lower than WHO (2003) and FEPA (2004) recommended limits in drinking water, while $\mathrm{Mn}$ and $\mathrm{Pb}$ were higher than these limits. The implication of this finding is that whereas $\mathrm{Cd}, \mathrm{Ni}, \mathrm{Cu}$ and $\mathrm{Zn}$ posed no health hazards to fish and consumers in the study area, $\mathrm{Mn}$ and $\mathrm{Pb}$ could pose health hazards in view of their high concentrations. The health hazards of heavy metals to fish as well as consumers of contaminated food/fish and fishery products are already well documented (Kurland et al., 1960; Alabaster and Lloyd, 1982; Heath, 1991; Ademoroti, 1996; Carvalho et al., 2004; Nussey et al., 2006).

\section{Conclusion}

The results of this study have shown that underground (bore-hole) water across the three districts of Edo State is suitable for aquaculture, drinking and other domestic uses, judging from the acceptable levels of most of the parameters analyzed in this study. However, because of the high concentrations of $\mathrm{Mn}$ and $\mathrm{Pb}$ in the water, which exceeded WHO, 2004 recommended limits in water and the slightly low $\mathrm{pH}$, which could pose problems, especially in aquaculture, some degree of treatment with lime is recommended. This could increase the $\mathrm{pH}$ to desired levels and also reduce the concentrations of the heavy metals through precipitation and or adsorption to sediment particles in aquaculture facilities and thus lead to production of suitable fish for consumers.

\section{REFERENCES}

Abohweyere PO. 1990. Study of limnological parameters and potential yields in Kainji, New Bussa, Nigeria. Journ. of Aquatic Sciences, 5: 53-58. 
Ademoroti CMA. 1996. Environmental Chemistry and Toxicology. Foludex Press Ltd.: Ibadan; 215p.

Akolisa O, Okonji VA. 2005. A review of Environmental implications of Aquaculture Development in Nigeria; Strategies to minimize Environmental Impacts. Proceedings of the $20^{\text {th }}$ Annual Conference of the Fisheries Society of Nigeria (FISON), Port Harcourt on 1418th Nov. 2005, pp. 225-229.

Alabaster JS, Lloyd R. 1962. Water quality Criteria for freshwater pond in Uyo, Nigeria. Tropical Freshwater Biology, 4: 65-81.

Asonye CC, Okolie NP, Oken EE, Iwuanyanwu UG. 2007. Some physicochemical characteristics and heavy metal profiles of Nigerian rivers, streams and waterways. Afric. Journ. of Biotech. (AJB), 6(5): 617-624.

Beauchamp RSA. 1953. Sulphates in African Inland Waters. Nature. Lond., 171: 769 771.

Biney CA, Amuzu AT, Calamari D, Kaba N, Mbome IL, Neave H, Ochumba PBO, Osibanjo O, Radegonde V, Saad MAH. 1991. Review of heavy metals in the African Aquatic Environment. FAO Fisheries Report, 471: 7-43.

Bond GG, Straub CP, Prober R. 1973. Handbook of Environmental Control. Water Supply and Treatment ( Vol. 111). CRC Press: Ohio; 835p.

Boyd CE. 1979. Water Quality in Warm Fish Ponds. Alabama University Agricultural Experiment Station: Alabama; 339p.

Canada Drinking Water Standards and Objectives. 1968. Department of National and Welfare, Ottawa, Canada.

Carvalho CS, Araujo HSS, Fernandez MN. 2004. Hepatic metallothionein in a teleost (Prochilodus scrofa) exposed to copper at pH 4.5 and 8.0. Comp. Biochem. Physiol., 137b: 225-234.

CIFA (Committee for Inland Fisheries in Africa). 1994. Review of pollution in the African aquatic environment. CIFA, Tech. Paper 25. FAO, Rome, 1994, 118p.

DEAT (Department of Environmental Affairs Tourism). 1999. State of freshwater systems and resources, SA.htt://www.ngo. grida.no/soesa/nsoer/issues/water/state4. htm.
Delgado CL, Wada N, Rosegrant MW, Major S, Ahmed M. 2003. Fish to 2020, Supply and Demand in Changing Global Markets. Int. Food Policy Res. Inst.: Washington, DC; 226p.

DPR (Department of Petroleum Resources). 1999. Environmental Guidelines and Standards for the Petroleum Industry in Nigeria, (EGASPIN), (Revised edn 2002); 26p.

DWAF (Department of Water Affairs and Forestry). 1993. South African Water Quality Guidelines (Vol. 1; $1^{\text {st }}$ edn). Domestic Use: South Africa; 216p.

Edokpayi AE, Osimen EC. 2001. Hydrological studies in Ibiekuma River in Ekpoma, Southern Nigeria after Impoundment: The Faunal Characteristics. Afr. Journ. of Sci. and Tech. (AJST), Science and Engineering Series, 2(1): 72-81.

Egborge ABM. 1994. Water pollution in Nigeria: Biodiversity and Chemistry of Warri River. Ben Miller Books Ltd; $331 \mathrm{p}$.

Essiensberg Consultants Limited. 1994. Feasibility report for the establishment of fruit juice processing and packaging plant in Benin City, Edo State, Nigeria, 52p.

Etienne B, Moreau J, Bouda S. 1997. Hydrological aspects of fisheries in small reservoirs in the Sahel Region. Tech. Centre for Agric. and Rural Cooperation, ACP-EU, 233p.

FAO (Food and Agriculture Organization). 1992. Report of the third session of the working party on pollution and fisheries, Accra, Ghana, 25-29 $9^{\text {th }}$ Nov. 1991. FAO Fisheries Report, 471, 43p.

FEPA (Federal Environmental Protection Agency). 2003. Guidelines and standards for environmental pollution control in Nigeria, 238p.

Forstner U, Wittmann GTW. 1981. Metal Pollution in the Aquatic Environment. Spring-Verlag: Berlin, Heidelberg, New York; 486p.

Gietema B. 1992. Fish Farming in Ponds and Integrated Farming. Gbemi Sodipo Press Ltd.: Sapon, Abeokuta, Nigeria; 143p.

Heath AG. 1991. Water Pollution and Fish Physiology. Lewis Publishers: Boca Raton, Florida, USA. 359p. 
Idodo-Umeh G. 2002. Pollution assessments of Olomoro water bodies using physical, chemical and biological indices. $\mathrm{PhD}$ thesis, University of Benin, Benin City, Nigeria, $485 \mathrm{p}$.

Ihuahi JA, Omojowo FS. 2005. Quality and Safety of Aquaculture Products: A Review. Proceedings of the $20^{\text {th }}$ Annual Conference of the Fisheries Society of Nigeria (FISON), Port Harcourt, $14^{\text {th }}-18^{\text {th }}$ November, 2005. FISON, 2005, pp. 545549.

Izevbigie ER. 2005. Water Quality Management in Fish Pond. Paper Presentation of Agriculture Development Agency (ADP): Fish Farmers Workshop on Nov. 10, 2005, pp. 1-6.

Kurland LT, Faro SW, Siedler H. 1960. Minamata Disease: The outbreak of a Neurological disorder in Minamata, Japan and its relation to ingestion of sea food containing mercury compounds. World Neurol. 1: 370-495.

Kutty MN. 1984. Site selection for aquaculture-chemical features of water. African Regional Aquaculture Centre, Port Harcourt, Nigeria, ARAC/87/WP/ 2(9), 53p.

Lloyd RM. 1965. Factors that affect the tolerance of fish to heavy metal poisoning: Biological problems in water pollution, $3^{\text {rd }}$ Seminar 1962. U. S. Dept. Health, Education and Welfare, 181p.

Nussey G, Van Vuren JHJ, Du Preez HH. 2006. Bioaccummulation of $\mathrm{Cr}, \mathrm{Mn}, \mathrm{Ni}$ and $\mathrm{Pb}$ in the tissues of Moggel, Labeo umbratus (Cyprinidae) from Witbank Dam Mpumalanga. Water SA, 2(26): 269284.

Ogbeibu AE, Ezeunara PU. 2002. Ecological impact of brewery effluents on the Ikpoba river, using the Fish Communities as Bioindicators. Journ. of Aquatic Resources, 17(1) : 35-44.

Ogbeibu AE, Victor R. 1995. Hydrological studies of water in the Okomu forest reserve sanctuary in Southern Nigeria: Physical and Chemical Hydrology, 4: 83100.
Oguzie FA. 2003. Heavy metals in fish, water and effluents of lower Ikpoba river in Benin City, Nigeria. Pakistan Journal of Sci. and Industrial Res., 46(3): 156-160.

Olaniyi T. 2005. Going fishing. TELL Magazine No. 34: 67-68.

Olowosegun OM, Olowosegun T, Mohammed H. 2005. A Review of Water pollution on the fish and fishing industry in Nigeria. In Proceedings of the $20^{\text {th }}$ Annual Conference of the Fisheries Society of Nigeria (FISON), Port Harcourt, Nigeria, $14^{\text {th }}-18^{\text {th }}$ November, 2005, pp. 423-428.

Parker NC. 1986. Stress and its Implications in cultured fishes. Trans. Amer. Fish Soc. 106: $167-177$.

Sutcliffe TR, Carrick JH, Rigg E, Talling JF, Woof C, Lund JW. 1998. Long term and Seasonal changes in the chemical composition of Precipitate and Surface Water of Lakes and Terns in the English Lake District; Freshwater Biology, 12: 451-505.

Tait RV. 1968. Elements of Marine Ecology: An Introductory Course. Butterworth and Co. Publishers Ltd.: London, 88 Kingsway W. C. 2; 272p.

Committee on Water Quality Criteria. 1968. Report of the Committee on Water Quality Criteria, Federal Water Pollution Administration, USA Department of Interior, Washington DC.

Wetzel GW. 1975. Limnology. W. B. Saunders Company: Philadelphia, London, Toronto; 743p.

Williams M. 1996. The transition in the contribution of living aquatic resources to food security. International Food Policy Research, Washington DC, 4p.

WHO (World Health Organization). 2003. International Standards for Drinking Water ( $2^{\text {nd }}$ edn). WHO: Geneva.

WHO (World Health Organization). 2004. Guidelines for drinking water quality. In World Health Organization Criteria and other Supporting Information (Vol. $1 ; 3^{\text {rd }}$ edn). WHO: Geneva; 145-196. 